\title{
13 \\ The Politics of Property: Gender, Land and Political Authority in Solomon Islands
}

Rebecca Monson

\section{Introduction}

In his 2012 New Year's address to the nation, Solomon Islands' GovernorGeneral Sir Frank Kabui warned that land tenure had become the issue most likely to spark conflict within the scattered archipelagic nation. He went on to outline a number of issues he perceived to be a problem, including: the 'communal' ownership of land by kin groups and the need to register land in order to make it 'marketable'; the inequitable distribution of natural resource rents; and the 'illegal occupation' of land in the vicinity of the national capital, Honiara, by migrants from other islands. He exhorted Solomon Islanders to 'adjust our mindset' or remain 'caught between our cultural way of life and the cash economy' (Damosuaia 2012).

The core themes of Sir Frank Kabui's address-transformations in customary tenure, social differentiation, and capitalist developmentoccupy a prominent position in politics, not only in Solomon Islands, but across Melanesia. Indeed, recent conditions and events in Solomon Islands have sometimes been seen as exemplifying regional concerns about land, development and conflict in the wider region. From 1998 to 2003, 
Solomon Islanders experienced a period of civil conflict, popularly known as 'the Tension', during which hundreds of people died, tens of thousands were displaced, and the country's economy collapsed. Although land scarcity is not a major issue in Solomon Islands, Solomon Islanders continue to perceive disputes over customary land to be a major source of social inequality and conflict.

As is the case elsewhere in Melanesia, the state in Solomon Islands is often described as 'weak' when it comes to land governance and administration, and in any event, most land is formally governed by customary tenure. In broad terms, this means that land tenure revolves around the occupation and use of a named place, by a named group, whose members trace their descent through men, women or both, to an apical ancestor or ancestors. Landholding and social ordering vary immensely across the country, but people generally lay claim to both land and membership of a kin group by invoking histories of their ancestors' origins and migrations. These stories are etched out across the land and sea, punctuated by important sites such as abandoned villages, old gardens, and significant trees. Contemporary land tenure therefore hinges on received ancestral models of land, territory and kinship. However, these models have also been recalibrated as people have engaged with Christian ideas and institutions, state laws and institutions, and an economy that is highly dependent on extractive industries. One of the most striking features of land tenure in Solomon Islands - in some parts of the country more than others-is the extent to which Solomon Islanders establish, assert, and defend their claims, not only by drawing on customary and state-based norms and institutions, but also norms and institutions rooted in Christianity. Contemporary land tenure is therefore characterised by multiple, overlapping arenas, norms and institutions emanating from kastom, Christianity and the state as they vary from one community to the next (Monson 2012; see also Scott 2007).

This means that land tenure in Solomon Islands is far from static, but dynamic and negotiable, with people asserting claims to land by drawing on a range of vocabularies, narratives and institutions. These qualities of indeterminacy and negotiability have been emphasised in much of the recent scholarship on land and natural resource tenure in Melanesia. This literature often draws on ethnographic research in Papua New Guinea, and focuses on innovations in landholding and sociality elicited by mining and forestry (Brown and Ploeg 1997; Wagner and Evans 2007; Weiner and Glaskin 2007). While attention has been paid to 
the ways in which the negotiation of 'ownership' is linked to increased social and economic differentiation (Rodman 1987; Zimmer-Tamakoshi 1997; Koczberski and Curry 2004; Bainton 2008), the links between 'local' contests over land and wider processes of state formation remain relatively under-explored. This is a theme that has received far greater attention in the literature on sub-Saharan Africa, which emphasises that the negotiation of land tenure is bound up with the contestation and assertion of political authority and leadership, whether by 'local' actors such as chiefs, or by representatives of the post-colonial nation-state. ${ }^{1}$

This chapter links questions about social differentiation in land relations in Solomon Islands to debates about gender inequality in the exercise of formal political authority. I demonstrate that, although land tenure is dynamic and contested, different people are differently positioned to influence the outcomes of negotiations over land. In particular, once contests over land enter the arenas established by the state, it is primarily male leaders - often referred to as 'chiefs' - who perform, endorse and reject claims to land as property. While the dominance of senior men in these arenas is often perceived by foreign observers as rooted in 'customary' ideas about 'who may talk' about land matters, I suggest that it is also linked to long-term processes of colonial intrusion, missionisation, and capitalist models of development.

In this chapter, I argue that an individual's ability to solicit the state's recognition of claims to land is not merely linked to their political authority, but that property and authority are in fact mutually constitutive. As is the case in neighbouring Papua New Guinea and Vanuatu, the Solomon Islands' economy has always been heavily dependent on agricultural development and exploitation of natural resources. This means that soliciting the state's recognition of claims to land, trees and other resources has become a vital avenue to economic and political power and prestige in contemporary Solomon Islands.

The relationship between property and authority also means that land disputes have implications that stretch far beyond the local contexts in which they initially arise. The recursive constitution of property and authority through the state tends to consolidate control over land in

1 As Sara Berry puts it, 'contests over land involve contests over authority as well as resources: they draw on and reshape relations of power as well as property' (Berry 2002: 656; see also Lund 2008; Sikor and Lund 2009). 
the hands of a small number of men, while reproducing state norms and institutions as a masculine domain. Thus contests over land not only reflect social differentiation but constitute it; and processes of inclusion and exclusion at the national level are intimately entwined with the construction and re-inscription of categories of difference through contests over the 'ownership' of land at the local level.

\section{Property and Emergent Inequality}

Land tenure systems in Solomon Islands are dynamic, with multiple pathways for making, contesting and sanctioning claims through kastom, Christianity and the state. However, not all people are equally well positioned to influence the outcomes of negotiations, particularly as they occur across different arenas. Indeed, once contests over land enter the arenas established by the state, such as land acquisition procedures, it is primarily male leaders who perform, endorse and reject claims to land as property. Women are rarely listed as land trustees or timber rights holders, and they are largely absent from records of public hearings, suggesting that their role within the formal legal system is constrained. This is not to suggest that women - or indeed many men within communities - are unable to exert any influence over land deals and disputes. As I have argued elsewhere, women have had highly visible roles in all of the customary feasts I have observed, and their strategies for influencing land deals range from informal conversations within the household to staging large-scale protests (Monson 2011, 2012, 2014). However, across Solomon Islands, men and women alike express concern that logging, mining and the sale or leasing of land are occurring to the benefit of a small number of men, while many men and most women are excluded both from negotiations regarding these arrangements and the financial benefits that flow from them. Notably, all of these arrangements involve particular claims to land (or, in the case of logging, trees) being recognised, legitimated and consolidated by state legal and administrative systems. Thus, while Solomon Islanders gain and maintain access to resources in a variety of ways, it is primarily senior male leaders who are involved in making and adjudicating claims to land as property; and it is often senior male leaders who stand to gain the most from the legitimation of property by politicolegal institutions such as chiefs and courts (see Sikor and Lund 2009; Hall et al. 2011). 
These inequalities are thrown into sharp relief in struggles over land in Kakabona, a series of densely populated settlements built along the coastline to the immediate west of the Honiara town boundary. ${ }^{2}$ These villages are occupied by a number of matrilineages, widely referred to in Pijin as traeb ('tribes') and subtraeb ('subtribes'). Each of these matrilineages is associated with one of two moieties, and there is a prohibition on intra-moiety marriage-historically, villages were made up of two intermarrying groups.

Land in Kakabona is held under various tenure arrangements. Most of the land in the immediate vicinity of the Honiara town boundary has been registered and leased under the Land and Titles Act. In formal legal terms, this means that it is no longer considered 'customary land'. These parcels are registered in the names of a small number of male leaders who, under the terms of the Land and Titles Act, are representatives of the landholding group. The extent of registration declines as one moves east along the highway and away from Honiara, and customary land tenure becomes predominant. Significant tracts of land in this area are claimed by the members of one particular matrilineage, who base their claim on their descent from those who originally settled and cleared the land. However, in the last 30 years there have been a series of transactions through which some of this land has been divided up and distributed among a number of landholding groups. While these transactions often involve cash and are increasingly commercialised, they are also rooted in customary practice. Most involve feasting or tsupu, the ceremonial exchange of gifts, particularly food and shell money. The maintenance of claims to land depends on these feasts and ceremonies being remembered through oral histories and emplaced genealogies, known as tutungu (Scott 2007; Monson 2012).

Oral histories and government records indicate that social conflict and legal disputes regarding land in Kakabona intensified as the urbanisation of Honiara gathered pace during the 1970s. Indigenous villages on the outskirts of Honiara grew as indigenous Guale people relocated from more remote areas. While migrants from other islands initially settled on government land inside the town boundary, these settlements quickly began to spill out onto customary land. By the 1980s, disputes concerning land in Kakabona were regularly coming before the chiefs and courts,

2 Despite their proximity to the national capital, villages in Kakabona have received only very limited scholarly attention. 
often triggered by attempts to register and then lease or sell blocks of land under the Land and Titles Act. With just one notable exception, all of the disputes I examined involved men coming before the courts to make claims on behalf of the landholding group, and in all of the cases, the members of dispute resolution forums (whether chiefs or courts) were men.

Transcripts of hearings before chiefs and courts reveal that the claims made by senior men revolve around: highly complex and non-linear oral histories of origin and migration; descriptions of boundaries and sacred sites; repeated prestations across several generations; and intermarriage between groups and the birth of descendants. These tutungu reveal that land tenure on Guadalcanal was historically characterised by a complex web of nested and overlapping interests, with particular matrilineages living in close proximity to one another and regularly intermarrying. Disentangling the history of territorial claims is further complicated by the fact that oral histories suggest that the population of this part of Guadalcanal was quite mobile well into the twenty-first century. Indeed, it appears that it was not until the 1950s that sizeable, permanent settlements began to develop in Kakabona (Scott 2007; Monson 2012). However, the process of registration under the Land and Titles Act 1996 requires that land acquisition officers, chiefs and courts legitimate the claims of some kin groups and not others to 'ownership' of the land. While exclusive claims are rarely (if ever) made, courts often construct a hierarchy of claims, describing other groups as 'living under' the identified 'owners'. Under Section 195(1) of the Act, the process of registration also requires the identification of individuals who may be registered as the 'duly authorised representatives' of the landholding group, and joint owners on a statutory trust. These individuals are, with few exceptions, the individuals who appear before land acquisition officers, chiefs and courts, on behalf of the successful tribe; and in the vast majority of cases they are senior male leaders.

Most of the current trustees were initially nominated by members of the landholding group when land registration began to gather pace during the 1980s. All are senior men within their landholding groups, and most are referred to as 'chiefs'. The appointment of these men can in some respects be traced to long-standing models of masculine leadership: historically, a senior male was usually the spokesperson for the family and kin group on all land-related issues. These spokespersons are often described, in Pijin, as having the 'ability to talk' about land matters. 
The idea of being 'able to talk' about land is important across Guadalcanal, and indeed many other parts of Solomon Islands. It depends partly on an individual's level of education and skill in managing land relations within the landholding group, as well as with outsiders. Since women often have less access to education than do men, they are often less likely to possess the skills necessary to negotiate the state legal system and manage land transactions. Further, according to some Guadalcanal people, custom dictates that women no save tok ('cannot or should not talk') about land. People in Kakabona often explain that women should 'stand behind' the men when it comes to speaking about land and dealing with land in public arenas. This norm is often explained by reference to the role of men as warriors and protectors of women.

It is a principle of both kastom and the state legal system that these trustees consult with other members of the landholding group before dealing with the land. ${ }^{3}$ However, there is evidence that trustees have often failed to fulfil this obligation. Land in Kakabona has often been sold to migrants from other areas, as well as to local landholders who wish to move into new areas and establish new hamlets or gardens. Many of these sales have been made by trustees, although other members of landholding groups have also sold land. These deals are often struck by individuals in exchange for cash rather than through the traditional tsupu (feast), without adequate consultation of other members of the landholding group, and without distributing the proceeds of sale. As a result, land transactions are often highly controversial and a significant source of conflict.

This suggests that received ancestral models of leadership are now being translated into the state legal system in a manner that turns the customary 'ability to speak' about land into increasingly individuated control over land. People often explain that these trustees were nominated at the time of registration because they were 'big men' and skilled spokespersons who were trusted to represent the interests of the group. However, registration fixes their control over land and the wealth that flows from it, enhancing their authority over land vis-à-vis other members of the landholding group even further. Thus, while the dominance of senior men in state legal arenas may be partially traced to 'customary' ideas about 'who may talk' about land matters, it also needs to be understood in terms of the structural characteristics of the state legal system, which have worked to

3 See, for example, the then Chief Justice Muria's comments in Kasa v Biku [2004] SBHC 62. 
facilitate the simplification of the land tenure system and enable certain male leaders to consolidate their authority over land, people and kastom. Furthermore, I suggest that the dominance of senior men in state legal arenas also needs to be understood in terms of long-term processes of colonial intrusion, missionisation, and capitalist models of development.

\section{The Recursive Constitution of Property and Authority}

An individual's ability to solicit the state's recognition of claims to land is closely entwined with the political authority they enjoy. Indeed, following Christian Lund (2008), I suggest that property and authority are in fact mutually constitutive. Since the earliest period of colonisation, the pursuit of control over natural resources in Solomon Islands has been tightly bound up with the assertion, consolidation and dispersal of political authority. This has occurred at multiple scales, ranging from localised struggles over the territory between adherents to different missions, to constitutional debates about federalism and freedom of movement.

With the notable exception of Alice Pollard's work (2007), the scholarly literature on Solomon Islands focuses on male institutions of leadership and pays very little attention to the political roles and power of women prior to colonisation. Two key characteristics emerge from this literature. First, in many societies, male leadership appears to have been characterised by a triumvirate of idealised leadership functions involving a leader in warfare; an entrepreneurial feast giver; and a religious leader. ${ }^{4}$ For example, on Guadalcanal, these idealised masculine roles were concentrated in the taovia (often referred to in Pijin as jif or big man), malaghai (warrior), and vele (sorcerer). It is important to note that oral histories in Guadalcanal, as in many parts of Solomon Islands, clearly indicate that the idealised roles of the chief and warrior often overlapped and found expression in a single person (Aswani 2008).

Second, in many parts of Solomon Islands, male leaders gained prestige primarily by winning followers and mobilising people and resources in warfare, feast giving and ceremonial occasions. The taovia of Guadalcanal

4 For Malaita, see Hogbin (1939) and Keesing (1978); for Marovo, see Hviding (1996); for Guadalcanal, see Kabutaulaka (2002). 
were never assured of their status as leaders, but required to constantly compete with others by: making prestations of pigs and shell valuables; mobilising dancers and bamboo pan pipers; establishing large gardens; and leading warfare (Hogbin 1934, 1937, 1964; Bathgate 1993). Hereditary preference played a larger role in some parts of the country, but still depended largely on the ability to gain prestige. In the New Georgia group, the role of the bangara was generally achieved through a combination of male primogeniture, alliance through marriage, and leadership ability (Hviding 1996). A man who demonstrated exceptional skill as a warrior and leader, and who built up and distributed wealth, might become a bangara; and equally, a young man who lacked these qualities might be overlooked in favour of a more capable uncle, brother or cousin. Political leadership was therefore achieved more than it was ascribed, and characterised by a high degree of contestation.

Missionisation, the development of the cash economy, and the 'pacification' policies of the colonial authorities all worked to transform these pre-colonial systems of male leadership. The idealised masculine role of the warrior receded with the cessation of warfare; and though the fear of the power of pre-Christian religious authorities never disappeared altogether, it probably abated in the face of the new source of spiritual power promoted by Christian missionaries. European missionaries often regarded feasts as a waste of resources and actively discouraged them, contributing to a decline in an important path to prestige and increasingly individuated control over wealth. While wealth had previously been distributed throughout the community in order to gain prestige, it was increasingly used by the individual who earned it (Hogbin 1934: 252). However, many of the old avenues to prestige were in decline just as new opportunities to assert and consolidate authority were opening up. The 'big men' within communities were among the first to engage in commercial trade, and the language and commercial skills they acquired through trade with Europeans soon enabled them to sell land to Europeans and retain the financial benefits of such transactions. Those men who could speak English or Pijin were able to further consolidate their authority following the implementation of a system of indirect rule that involved the identification and appointment of 'village headmen' and 'constables'. Indirect rule, like the new commercial opportunities opened

5 British colonial regimes in Melanesia, like those elsewhere in the world, sought to establish and exercise administrative control through a version of indirect rule (see Berry 1992). 
up by colonisation, provided new avenues for the enactment of political authority and territoriality-opportunities that were overwhelmingly concentrated in the hands of those men who were able to convince British colonial officers and foreign planters to recognise them as leaders, 'chiefs', and the 'owners' of the land.

Processes of rearrangement of customary tenure and leadership therefore worked to legitimate and consolidate the authority of some segments of customary polities while de-legitimating and undermining others. In particular, leadership roles historically associated with women were usually overlooked and ignored. While existing scholarly literature pays very little attention to the political authority of women prior to colonisation, oral histories often attest to its importance. For example, the Bareke people of central Marovo Lagoon frequently refer to the fact that they historically had three important institutions of leadership: the bangara, siama, and vuluvulu. The bangara is often translated in Pijin as jif (chief), while the role of the siama was tied to pre-Christian religious beliefs and precolonial warfare. The term vuluvulu has multiple meanings, one of which refers to the people who constitute the blood core of a matrilineage. The term is also used to refer to particular women of high standing and, in this sense, is often translated as meaning the 'first born girl', the 'oldest female', a 'princess' or a 'queen'. However, European missionaries and colonial administrators alike consistently recognised some segments of the local polity, notably the idealised masculine role of the bangara, while seemingly unaware of the vuluvulu and actively undermining the siama. For example, European missionaries incorporated the term bangara into Christian liturgies and hymns, and Protectorate officials perceived kastom as collapsing political authority and control over land into the single figure of the bangara (Monson 2011). This enabled the bangara to convert their historical roles as group leaders to those of 'chiefs' and 'landowners', strengthening their political power in a context where customary forms of land tenure and leadership were already being renegotiated, and customary leaders were struggling to secure their continued relevance.

Perhaps the pre-eminent example of such a leader is Ngatu, a man from Marovo Lagoon who successfully negotiated the multitude of changes occurring during the early twentieth century. Despite being unable to assert his authority as a warrior due to the 'pacification' policies of the colonial authorities, Ngatu was able to negotiate new paths to prestige by attaching himself to the new orders of the church and state. He introduced Methodism to Marovo and became a critical leader within 
the Methodist mission. He was able to use his reputation as a 'chief' or 'big man' to sell land to the government, and to generate cash through the establishment of a large-scale cooperative scheme of copra production, transport and marketing (Bennett 1987: 116, 224). The introduction of indirect rule consolidated Ngatu's authority even further-he was appointed District Headman for Marovo, and held the post until it was abolished in the 1940s, at which point he became a member of the Native Court instead. Court records, oral histories and written histories all indicate that Ngatu was very heavily involved in determining land disputes (Carter 1981: 60). His position as bangara and his appointment by Protectorate officials must have had a recursive effect, for in the process of legitimating some claims to land, and not others, Ngatu's authority was simultaneously reinforced. Put another way, as local claimants sought to secure their rights to land by having their claims recognised by Ngatu, that process worked to consolidate Ngatu's authority in the eyes of both local people and Protectorate officials. Indeed, Ngatu was so successful in consolidating his authority within each of the arenas of kastom, church and state that he ultimately became regarded as the 'chief' of a huge area, from Nggatokae to Ramata.

Processes of adaptation, contestation and legitimation of claims to both natural resources and politico-legal authority have therefore worked to benefit some segments of the customary polity more than others, with implications for property and authority today. Marovo is well known not only as a major tourist destination in Solomon Islands, but as the site of some of the most socially and environmentally destructive logging in the country. This occurs under the Forest Resources and Timber Utilisation Act 1978, which provides (in Section 7) that any person who is interested in logging customary land must apply to the Commissioner of Forest Resources for consent to negotiate with the relevant government authorities and the 'owners' of land and timber rights. In theory, under Sections 8 and 9, the relevant provincial government then holds a 'timber rights hearing' at which it determines a range of issues, including who holds timber rights; who the customary landowners are; and how profits are to be shared. ${ }^{6}$ This information is then recorded in a 'certificate of customary ownership', commonly known as a 'form two'. The individuals

6 Note also that the courts have interpreted the Act to distinguish between ownership of customary land and ownership of trees: Allardyce Lumber Company Limited [1989] SBHC 1; Gandley Simbe $v$ East Choiseul Area Council [1997] SBHC 67; Mateni v Hite [2003] SBHC 144. This distinction has added to the complex maze of claims, negotiations and contracts associated with logging. 
listed in the 'form two' are deemed to be entitled to negotiate with the logging company. Under Part III of the Act, there is a right of appeal to the Customary Land Appeal Court, the decision of which is final and conclusive, subject only to the original jurisdiction of the High Court.

The regulation of forestry in Solomon Islands is notoriously complex, and the problems surrounding logging have stimulated a wealth of research on collusion between foreign logging companies and local politicians, irregularities in the timber rights hearing process, poor monitoring and enforcement, and the uneven distribution of royalties (Frazer 1997; Dauvergne 1998; Bennett 2000; Kabutaulaka 2000, 2001; Wairiu 2007; Wairiu and Nanau 2010; Allen 2011a; McDougall 2011). The Forest Resources and Timber Utilisation Act presupposes that it is possible to identify and mark boundaries between social groups, as well as delineate the 'land' and 'timber' to which they hold 'rights'. As a result, debates about the 'ownership' of land and trees in timber rights hearings and before courts often revolve around competing unilineal interpretations of customary tenure (Hviding 1993, 2002; Foale and Macintyre 2000). The process of making and legitimating claims to land and trees as property results in relationships between people bound by generations of shared descent and shared use of the land being fractured or 'cut' (Strathern 1996; Blomley 2011). In at least one instance, the process of disentangling people and marking off social identities and land claims has precipitated protracted litigation between a father and son. ${ }^{7}$

Women and men are differently positioned to influence the outcomes of negotiations with logging companies and contests before provincial authorities and courts. In practice, negotiations between logging companies and landowners have often been underway for a significant period before the issue of a 'form two'. While forested land is widely regarded as being the collective territory of the kin group in Marovo, representatives of logging companies often focus their efforts on negotiating with particular individuals who are identified as being influential with the landowning group and are in favour of logging (Wairiu 2007; Kabutaulaka 2008: 252). In many instances, proponents of logging form 'companies', a process that involves the appointment of particular individuals as company directors (see Scales 2003: 105; also Kabutaulaka 2008: 252, 2011: 7 ,

7 I have not cited the case here in order to preserve the privacy of the parties. However, the ongoing dispute resulted in at least nine determinations in the High Court and the Court of Appeal between 2003 and 2010 . 
104-5, 185ff). The individuals who are appointed as company directors, involved in negotiations, and signatories to agreements are nearly (if not always) men-some are recognised as chiefs, and some are younger, entrepreneurial individuals who are likely to be recognised as chiefs in the future (Hviding and Bayliss-Smith 2000). ${ }^{8}$ Many of the younger men have become powerful due to their relatively high level of formal education and literacy, their understanding of regulatory frameworks governing forestry, and their ability to persuade elderly_-sometimes illiterate—senior men to endorse and promote logging. ${ }^{9}$ As was the case with traders, missionaries and colonial administrators before them, loggers and provincial authorities today wish to identify and engage with individuals rather than entire matrilineages - a process that is facilitated by the requirements of the state legal system. This has enabled a small number of individuals to carve out a 'big man' status and strengthen their power base within their matrilineage by obtaining and distributing logging revenue (Bennett 1987, 2000; Wairiu 2007). These processes have implications that stretch far beyond the local contexts in which they initially arise.

\section{Property, Authority and Post-Colonial State Formation}

Despite the manifest weaknesses of the state in Solomon Islands, it has nevertheless constructed and recognised a structure of entitlements for some people while diluting the claims of others (Lund 2008: 8-9). This has resulted in processes of gendered social differentiation, in which the semantic and institutional structures of the state have been reproduced as masculine domains. It is generally senior men who mobilise the language of state law on behalf of the group before chiefs and courts, men who are constructed as the defenders of the land against incursion, senior men who are constituted as 'trustees', and therefore senior men who control the access to revenue so crucial for participation in provincial and national politics. These processes have not only ensured that land disputes remain a critical arena for the performance of particular models of masculinity, but have produced and reinscribed state institutions as a masculine domain.

8 There are also similarities with the practices regarding mining (see Hviding 1993).

9 See also Kabutaulaka (2000, 2001), who emphasised generational differences between men in relation to logging on Guadalcanal. 
Since the earliest period of colonisation, economic development in Solomon Islands has been based primarily on the extraction of natural resources by a relatively small number of large-scale, foreign-owned companies. Many of these operations are based on customary land, and the state bureaucracy acts as both regulator and intermediary between local communities and foreign companies. In this context, soliciting the state's recognition of claims to land and other natural resources has become a vital avenue to building economic and political power in contemporary Solomon Islands (Hameiri 2007a, 2009). A number of scholars have noted that parliamentarians in Solomon Islands invariably have substantial logging interests (Bennett 2000; Hviding and BaylissSmith 2000; Allen 2011a), and similarly, many of the men who have been successful in establishing themselves as 'trustees' of registered land also hold significant roles in national and provincial politics.

Securing state recognition of territorial authority has therefore become an important means by which to assert authority, not only at the local level, but also in provincial and national politics. Provincial and national political organisation in Solomon Islands, as in neighbouring Papua New Guinea, is extremely unstable and fragmented. For various reasons, governing coalitions in Solomon Islands have been characterised by highly fluid alliances, in which political cohesion is maintained through highly personalised patronage networks, largely involving men (Dinnen 2008a, 2008b; Allen 2011b). Again like Papua New Guinea, Solomon Islands' heavy dependence on primary resources and foreign capital has meant that the bulk of cash required to support these patronage networks comes from the state, from revenues derived from natural resource extraction by foreign-owned corporations, and from foreign donors (Hameiri 2007a, 2007b; Dinnen 2009; Allen 2011a). As Sinclair Dinnen points out, this has worked to maintain social fragmentation and to disperse rather than centralise power (Dinnen 2009). The relative fragility of the state has contributed to a situation that Edvard Hviding has described as 'compressed globalisation', in which a relatively small number of actors engage with a variety of local and global actors, including multinational logging, fishing and mining companies, as well as conservationists and tourists (Hviding 2003) ${ }^{10}$ The fragility of government, combined with the relatively small and dispersed population, has allowed foreign commercial

10 Knauft (1999: 242) similarly suggests that Melanesia is notable for the ways in which 'the local intersects the global in axiomatically condensed forms'. 
actors and non-government organisations alike to largely bypass the central government and negotiate directly with communities. In some senses, this could be praised as contributing to decentralisation and strengthening indigenous control over natural resources. Yet in practice, control over negotiations is concentrated in the hands of a relatively small number of people, primarily male leaders. Thus local contests over land and leadership are entwined with broader processes of social differentiation and state formation that are often extremely condensed in both space and time (Hviding 2003).

The implications of these processes of social differentiation must be understood in symbolic as much as material terms. Land disputes have now become a key arena for the performance of masculine authority and prestige, and the ideal spokesperson of the group embodies not only the oratorical prowess, but also the aggression and independence, that was previously symbolised by the chief and warrior (Scott 2000). Put another way, the forms of authority, prestige and solidarity that were previously associated with chiefs and warriors now find their coalesced expression in the ideal representative of the social group in discussions and disputes regarding land. This serves to construct men, rather than women, as the ideal spokespersons of the group. Furthermore, the performance of authority in state arenas works to entrench the authority of particular male leaders over land, so that the roles of 'spokesperson' and 'trustee' are mutually constitutive.

The implications of these processes stretch from local-level struggles over land through to participation in the exercise of formal political authority at the provincial and national level. Solomon Islands has one of the worst records in the world in terms of women's participation in the national parliament. ${ }^{11}$ I suggest that the dominance of male leaders, and the absence of most women and many men from the courts and the parliament, are closely entwined. Soliciting the state's recognition of claims to land has become a vital, if not the pre-eminent, route to building masculine authority and prestige in contemporary Solomon Islands. The recursive constitution of property and political authority through the state therefore works to consolidate control over land in the hands of a small number of men, while simultaneously producing and reinscribing state norms and institutions as a masculine-even hypermasculine—domain.

11 Only two women have so far been elected to it: Hilda Kari held a seat for two terms in the 1980s, and in 2012, Vika Lusibaea was elected in a by-election for the seat formerly held by her husband. 


\section{Conclusion}

Customary land tenure in Solomon Islands is highly dynamic and negotiable, comprised of an ever-shifting mosaic of norms and institutions emanating from kastom, church and state. Such flexibility undoubtedly opens up multiple pathways for negotiating access to land, but not all of these pathways are equally accessible to all people. While members of landholding communities have a variety of means by which to claim access to land, once contests over land enter the arenas established by the state, it is primarily male leaders who perform and adjudicate claims to land as property. Indeed, these arenas have become crucial sites for the performance of masculine authority and prestige, meaning that property and authority are not only recursively constituted, but inscribed as masculine. Securing state recognition of control over land is therefore intimately intertwined not only with the performance of masculine authority and prestige at the local level, but also in provincial and national politics. The mutually constitutive relationship between property and authority works to consolidate control over land in the hands of a small number of male elites while reproducing state norms and institutions as a masculine domain. This means that contests over land cannot be dismissed as parochial struggles over economic resources, nor do they merely 'reflect' social differentiation. Rather, contests over property emerge from and are productive of social differentiation in ways that are not merely confined to 'the local,' but inextricably entwined with contests over belonging, citizenship, political authority, and state formation.

\section{References}

Allen, M., 2011a. 'The Political Economy of Logging in Solomon Islands.' In R. Duncan (ed.), The Political Economy of Economic Reform in the Pacific. Metro Manila: Asian Development Bank.

_ 2 2011b. 'Long-Term Engagement: The Future of the Regional Assistance Mission to Solomon Islands.' Canberra: Australian Strategic Policy Institute (Strategic Insights 51). 
Aswani, S., 2008. 'Forms of Leadership and Violence in Malaita and in the New Georgia Group, Solomon Islands.' In P.J. Stewart and A. Strathern (eds), Exchange and Sacrifice. Durham (NC): Carolina Academic Press.

Bainton, N.A., 2008. 'Men of Kastom and the Customs of Men: Status, Legitimacy and Persistent Values in Lihir.' Australian Journal of Anthropology 19: 194-212. doi.org/10.1111/j.1835-9310.2008. tb00122.x.

Bathgate, M., 1993. Fight for the Dollar: Economic and Social Change in Western Guadalcanal, Solomon Islands. Wellington: Alexander Enterprise.

Bennett, J.A., 1987. Wealth of the Solomons: A History of a Pacific Archipelago 1800-1978. Honolulu: University of Hawai'i Press (Pacific Islands Monograph 3).

—_, 2000. Pacific Forest: A History of Resource Control and Contest in Solomon Islands, c. 1800-1997. Cambridge: White Horse Press.

Berry, S., 1992. 'Hegemony on a Shoestring: Indirect Rule and Access to Agricultural Land.' Africa 62: 327-355. doi.org/10.2307/1159747.

—_, 2002. 'Debating the Land Question in Africa.' Comparative Studies in Society and History 44: 638-668.

Blomley, N., 2011. 'Cuts, Flows and the Geographies of Property.' Law, Culture and the Humanities 7: 203-216. doi. org/10.1177/1743872109355583.

Brown, P. and A. Ploeg (eds), 1997. Change and Conflict in Papua New Guinea Land and Resource Rights. Special issue 7(4) of Anthropological Forum.

Carter, G.G., 1981. Ti é Varané: Stories about People of Courage from Solomon Islands. Rabaul: Unichurch Publishing.

Damosuaia, D., 2012. 'Land Likely Cause of Conflict, G.G. Warns.' Solomon Star, 4 January.

Dauvergne, P., 1998. 'Corporate Power in the Forests of the Solomon Islands' Pacific Affairs 71: 524-546. doi.org/10.2307/2761083. 
Dinnen, S., 2008a. 'State-Building in a Post-Colonial society: The Case of Solomon Islands.' Chicago Journal of International Law 9: 51-78.

— 2008b. 'The Solomon Islands Intervention and the Instabilities of the Post-Colonial State.' Global Change, Peace and Security 20: 339-355. doi.org/10.1080/14781150802394063.

— 2009. 'The Crisis of State in Solomon Islands.' Peace Review 21: 70-78. doi.org/10.1080/10402650802690094.

Foale, S. and M. Macintyre, 2000. 'Dynamic and Flexible Aspects of Land and Marine Tenure at West Nggela: Implications for Marine Resource Management.' Oceania 71: 30-45. doi. org/10.1002/j.1834-4461.2000.tb02722.x.

Frazer, I., 1997. 'The Struggle for Control of Solomon Islands Forests.' Contemporary Pacific 9: 39-72.

Hall, D., P. Hirsch and T.M. Li, 2011. Powers of Exclusion: Land Dilemmas in Southeast Asia. Singapore: NUS Press.

Hameiri, S., 2007a. 'The Trouble with RAMSI: Re-Examining the Roots of Conflict in Solomon Islands.' Contemporary Pacific 19: 409-441. doi.org/10.1353/cp.2007.0052.

_ 2007b. 'Failed States or a Failed Paradigm? State Capacity and the Limits of Institutionalism.' Journal of International Relations and Development 10: 122-149. doi.org/10.1057/palgrave.jird.1800120.

_ 2009. 'State-Building or Crisis Management? The Regional Assistance Mission to the Solomon Islands and the Limits of State Transformation.' Third World Quarterly 30: 35-52. doi. org/10.1080/01436590802622276.

Hogbin, H.I., 1934. 'Culture Change in the Solomon Islands: Report of Fieldwork in Guadalcanal and Malaita.' Oceania 4: 233-267. doi. org/10.1002/j.1834-4461.1934.tb00110.x.

_ 1937. 'The Hill People of North-East Guadalcanal.' Oceania 8: 62-89. doi.org/10.1002/j.1834-4461.1937.tb00406.x.

- 1939. Experiments in Civilization: the Effects of a European Culture on a Native Community of the Solomon Islands. London: Routledge. 
—_, 1964. A Guadalcanal Society: The Kaoka Speakers. New York: Holt, Rinehart \& Winston.

Hviding, E., 1993. 'Indigenous Essentialism? "Simplifying" Customary Land Ownership in New Georgia, Solomon Islands.' Bijdragen tot de Taal-, Land-en Volkenkunde 149: 802-824. doi. org/10.1163/22134379-90003114.

—_, 1996. Guardians of Marovo Lagoon: Practice, Place and Politics in Maritime Melanesia. Honolulu: University of Hawai'i Press (Pacific Islands Monograph 14).

__ 2002. 'Disentangling the Butubutu of New Georgia: Cognatic Kinship in Thought and Action.' In I. Hoëm and S. Roalkvam (eds), Oceanic Socialities and Cultural Forms: Ethnographies of Experience. New York: Berghahn Books.

__, 2003. 'Contested Rainforests, NGOs, and Projects of Desire in Solomon Islands.' International Social Science Journal 178: 539-554.

Hviding, E. and T. Bayliss-Smith, 2000. Islands of Rainforest: Agroforestry, Logging and Eco-Tourism in Solomon Islands. Aldershot: Ashgate.

Kabutaulaka, T.T., 2000. 'Rumble in the Jungle: Land, Culture and (Un) sustainable Logging in the Solomon Islands.' In A. Hooper (ed.), Culture and Sustainable Development in the Pacific. Canberra: Asia Pacific Press.

_- 2001. Paths in the Jungle: Landowners and the Struggle for Control of Solomon Islands' Logging Industry. Canberra: The Australian National University (PhD thesis).

—_, 2002. Footprints in the Tasimauri Sea: A Biography of Domeniko Alebua. Suva: Institute of Pacific Studies.

—_, 2008. 'Global Capital and Local Ownership in Solomon Islands' Forestry Industry.' In S. Firth (ed.), Globalisation and Governance in the Pacific Islands. Canberra: ANU E Press.

Keesing, R.M., 1978. Elota's Story: the Life and Times of a Solomon Islands Big Man. St Lucia: University of Queensland Press. 
Knauft, B.M., 1999. From Primitive to Postcolonial in Melanesia and Anthropology. Ann Arbor: University of Michigan Press. doi. org/10.3998/mpub.10934.

Koczberski, G. and G.N. Curry, 2004. 'Divided Communities and Contested Landscapes: Mobility, Development and Shifting Identities in Migrant Destination Sites in Papua New Guinea' Asia Pacific Viewpoint 45: 357-371. doi.org/10.1111/j.1467-8373.2004.00252.x.

Lund, C., 2008. Local Politics and the Dynamics of Property in Africa. Cambridge: Cambridge University Press.

McDougall, D., 2011. 'Church, Company, Committee, Chief: Emergent Collectivities in Rural Solomon Islands.' In M. Patterson and M. Macintyre (eds), Managing Modernity in the Western Pacific. St Lucia: University of Queensland Press.

Monson, R., 2011. 'Negotiating Land Tenure: Women, Men and the Transformation of Land Tenure in Solomon Islands.' In J. Ubink (ed.), Customary Justice: Perspectives on Legal Empowerment. Rome: International Development Law Organization.

_ 2012. Hu Nao Save Tok? Women, Men and Land: Negotiating Property and Authority in Solomon Islands. Canberra: The Australian National University (PhD thesis).

— 2014. 'Unsettled Explorations of Law's Archives: The Allure and Anxiety of Solomon Islands' Court Records.' Australian Feminist Law Journal 40: 35-50. doi.org/10.1080/13200968.2014.931882.

Pollard, A., 2007. Painaha: Gender and Leadership in 'Are'Are Society, the South Seas Evangelical Church and Parliamentary Leadership. Wellington: Victoria University ( $\mathrm{PhD}$ thesis).

Rodman, M., 1987. Masters of Tradition: Consequences of Customary Land Tenure in Longana, Vanuatu. Vancouver: University of British Columbia Press.

Scales, I., 2003. The Social Forest: Landowners, Development, Conflict and the State in Solomon Islands. Canberra: The Australian National University ( $\mathrm{PhD}$ thesis). 
Scott, M., 2000. 'Ignorance is Cosmos, Knowledge is Chaos: Articulating a Cosmological Polarity in Solomon Islands.' Social Analysis 44(2): 56-83.

—_ 2007. The Severed Snake: Matrilineages, Making Place, and a Melanesian Christianity in Southeast Solomon Islands. Durham (NC): Carolina Academic Press.

Sikor, T. and C. Lund, 2009. 'Access and Property: A Question of Power and Authority.' Development and Change 40: 1-22. doi.org/10.1111/ j.1467-7660.2009.01503.x.

Strathern, M., 1996. 'Cutting the Network.' Journal of the Royal Anthropological Institute (NS) 2: 517-535. doi.org/10.2307/3034901.

Wagner, J. and M. Evans (eds), 2007. Customs, Commons, Property, and Ecology. Special issue 66(1) of Human Organization.

Wairiu, M., 2007. 'History of the Forestry Industry in Solomon Islands.' Journal of Pacific History 42: 233-246. doi. org/10.1080/00223340701461684.

Wairiu, M. and G. Nanau, 2010. 'Logging and Conflict in Birao Ward of Guadalcanal, Solomon Islands.' Honiara: Islands Knowledge Institute (Working Paper 1).

Weiner, J.F. and K. Glaskin (eds), 2007. Customary Land Tenure and Registration in Australia and Papua New Guinea: Anthropological Perspectives. Canberra: ANU E Press (Asia-Pacific Environment Monograph 3).

Zimmer-Tamakoshi, L., 1997. 'When Land Has a Price: Ancestral Gerrymandering and the Resolution of Land Conflicts at Kurumbukare.' Anthropological Forum 7: 649-665. doi.org/10.10 80/00664677.1997.9967478. 
This text is taken from Kastom, property and ideology: Land transformations in Melanesia, edited by Siobhan McDonnell, Matthew Allen and Colin Filer, published 2017 by ANU Press, The Australian National University, Canberra, Australia. 